\title{
Psikoterapi Interpersonal untuk Menurunkan Gejala Depresi pada Perempuan Korban Kekerasan dalam Rumah Tangga
}

\author{
YUDI KURNIAWAN* \& NOVIZA
}

Program Studi Psikologi, Fakultas Psikologi, Universitas Semarang

\begin{abstract}
ABSTRAK
World Health Organization (WHO) menggolongkan depresi sebagai salah satu permasalahan kesehatan yang mendesak untuk ditangani. Oleh karena itu, penulis melakukan intervensi psikologis berupa Psikoterapi Interpersonal untuk menurunkan gejala depresi perempuan korban kekerasan dalam rumah tangga. Skala yang digunakan dalam intervensi ini adalah Beck Depression Inventory (BDI-II) untuk menentukan tingkat depresi yang dialami partisipan. Analisis efektivitas terapi dalam intervensi dilakukan dengan menggunakan metode analisis deskriptif kuantitatif dengan menggunakan visual inspection, yaitu dengan melihat perubahan sebelum dan setelah diberikannya intervensi. Hasil yang diperoleh berdasarkan data deskriptif, rerata skor empirik depresi partisipan mengalami penurunan, apabila dibandingkan antara sebelum dengan sesudah dilakukan intervensi.
\end{abstract}

Kata kunci: depresi, kekerasan dalam rumah tangga, psikoterapi interpersonal

\begin{abstract}
World Health Organization (WHO) mentions depression as a health problem that urgently needs to be addressed. Therefore, we performed a psychological intervention, which was Interpersonal Psychotherapy to reduce depression symptoms of women were victims of domestic violence. The scale used in this psychological intervention was Beck Depression Inventory (BDI-II) to measure participants' depression severity. To investigate the effectiveness of our therapy we conducted quantitative descriptive analysis by using visual inspection. We calculated participants' depression level before and after intervention. The results obtained based on descriptive analysis, mean score of participants' depression level was reduced after intervention.
\end{abstract}

Keywords: depression, domestic violence, interpersonal psychotherapy

INSAN Jurnal Psikologi dan Kesehatan Mental, 2017, Vol. 2(2), 96-102, doi: 10.20473/jpkm.v2i22017.96-102 Dikirimkan: 21 Agustus 2017 Diterima: 13 Juli 2018 Diterbitkan: 19 Juli 2018 Editor: Atika Dian Ariana

*Alamat korespondensi: Jalan Soekarno-Hatta, Semarang, Jawa Tengah 50196. Pos-el: kurniawan.yudika@gmail.com

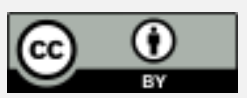

Naskah ini merupakan naskah dengan akses terbuka dibawah ketentuan the Creative Common Attribution License (http://creativecommons.org/licenses/by/4.0), sehingga penggunaan, distribusi, reproduksi dalam media apapun atas artikel ini tidak dibatasi, selama sumber aslinya disitir dengan baik. 


\section{PEN D A H U L U A N}

Kemajuan pembangunan di Indonesia membawa dampak positif maupun negatif bagi masyarakatnya, termasuk dalam kehidupan sosial. Dampak positif yang bisa kita rasakan adalah keterbukaan pola pikir terhadap teknologi yang dapat menunjang kehidupan, namun juga banyak dampak negatif yang terjadi, salah satunya menurunnya nilai-nilai normatif dalam masyarakat. Degradasi nilai mencakup nilai agama, nilai sosial, nilai moral, adat istiadat, dan nilai kesakralan sebuah keluarga. Kerukunan dan keutuhan rumah tangga yang bahagia, aman, dan tentram seolah semakin sulit ditemui. Seperti yang dapat dilihat saat ini angka kekerasan yang semakin meningkat, khususnya bagi kaum yang sering dianggap lemah yaitu pada perempuan dan anak. Di Jawa Tengah sendiri berdasarkan data yang dihimpun Legal Resources Center untuk Keadilan Jender dan Hak Asasi Manusia (LRC-KJHAM), sepanjang tahun 2015, terjadi 477 kasus kekerasan terhadap perempuan dengan jumlah korban 1.227 orang. Sementara berdasarkan sebaran wilayah Semarang menduduki peringkat pertama untuk kasus kekerasan terhadap perempuan yaitu sebanyak 177 kasus (Gumilang, 2017).

Segala bentuk tindak kekerasan baik terhadap perempuan maupun anak sudah medapatkan perhatian tersendiri bagi banyak pihak. Pemerintah sendiri sudah menindak tegas dan menyiapkan perangkat hukum yang memadai untuk menghapus tindak kekerasan tersebut. Tindak kekerasan di dalam sebuah keluarga tentu membawa dampak negatif baik fisik maupun psikologis korban. Berbagai penelitian menyebutkan bahwa pada umumnya korban kekerasan membawa resiko yang besar pada sisi psikologis. Perserikatan Bangsa Bangsa (PBB) menyebutkan bahwa kekerasan terhadap perempuan dalam rumah tangga membuat kerugian baik fisik, seksual, maupun psikologis. Ancaman, pemaksaan, bahkan sampai pada tindakan kekerasan sewenang-wenang harus dialami bahkan sampai berulangulang kali (Haqqi \& Faizi, 2010).

Keharmonisan rumah tangga menjadi dambaan bagi semua keluarga, di mana saling sayang menyayangi antar anggota keluarga, akan tetapi pada kenyataannya tidak semua keluarga dapat merasakannya. Bagi perempuan yang mendapatkan kekerasan dalam rumah tangga tentunya akan merasa sangat tertekan, dipenuhi rasa takut, trauma, stres, atau bahkan hingga depresi. Dampak kekerasan terhadap perempuan secara psikologis dijelaskan oleh Haqqi dan Faizi (2010) dalam penelitiannya bahwa kekerasan rumah tangga pada perempuan menyebabkan munculnya gejala depresi berat akibat trauma yang dialaminya. Penelitian serupa juga dijelaskan oleh Niaz (2003) juga menjelaskan bahwa $60 \%$ perempuan yang mengalami kekerasan dalam rumah tangga mengalami depresi berat hingga percobaan bunuh diri.

Korban KDRT umumnya sering menunjukkan perilaku yang inkonsisten karena kebingungan dalam mencari jalan keluar dari persoalan rumah tangganya. Di satu sisi, korban ingin berhenti menjadi korban kekerasan dengan cara bercerai, tetapi disisi lain persoalan anak dan ekonomi menjadi pertimbangan matang sehingga para korban kekerasan terus bertahan hingga bertahun-tahun. Perasaan tertekan, takut, kebingungan akan masa depan sering kali menjadi keluhan para korban. Hal tersebut diatas dapat ditarik kesimpulan bahwa dampak kekerasan pada perempuan sangatlah kompleks, khususnya secara psikologis. Beberapa gejala yang dikeluhkan merupakan bagian dari gejala depresi yang apabila dibiarkan akan membawa risiko besar bukan hanya bagi psikologisnya namun bisa beresiko pula bagi kesehatan fisik korban.

Apabila gejala depresi yang dialami perempuan korban kekerasan tidak tertangani dengan baik maka akan menimbulkan permasalahan lain, bahkan dapat menyebabkan kematian atau percobaan bunuh diri. WHO telah mengkategorikan depresi sebagai salah satu permasalahan klinis yang mematikan. Di dunia, depresi menjadi peringkat empat, dan diperkirakan akan meningkat menjadi peringkat dua pada tahun 2020 (Davey, 2008).

Intervensi yang selama ini dilakukan oleh pihak Seruni selaku pendamping korban KDRT sudah cukup membantu menyelesaikan permasalahan korban, namun masih ada beberapa gejala psikologis yang

INSAN Jurnal Psikologi dan Kesehatan Mental

2017, Vol. 2(2), 96-102

doi: 10.20473/jpkm.v2i22017.96-102

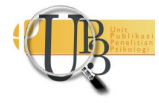


menetap karena stresor yang masih ada. Oleh karena itu penulis tertarik untuk melakukan intervensi lebih lanjut pada perempuan korban kekerasan. Salah satu intervensi yang mendapat dukungan dari American Academy of Pediatrics Mental Health dan telah terbukti efektif untuk kasus depresi yaitu Psikoterapi Interpersonal. Terapi ini pernah diteliti oleh Klomek, Zalsman, dan Mufson (2007). Psikoterapi Interpersonal merupakan intervensi berupa psikoterapi baru yang dikembangkan dan telah terbukti efektif untuk menangani permasalahan klinis, termasuk dalam kasus depresi. IPT sangat cocok untuk permasalahan yang terkait dengan konflik interpersonal seperti perceraian, kekerasan dalam rumah tangga, konflik berkepanjangan baik antara suami istri maupun anak dan orang tua.

IPT dikembangkan untuk penanganan depresi dan kemanjuran terapi ini didukung oleh hasil uji coba dalam jumlah skala besar. IPT terbukti efektif untuk menangani kasus depresi dengan pasangan, gangguan bipolar, gangguan makan, dan depresi. Dalam The International Society for Interpersonal Psychotherapy, IPT dikatakan sebagai terapi yang sederhana namun menjanjikan (Niaz, 2003). Oleh sebab itu, diharapkan dengan meningkatnya kemampuan interpersonal pada perempuan korban kekerasan, maka mereka akan mampu mengatasi gejala depresi yang dirasakan serta meningkatkan keterampilan komunikasi subjek, sehingga secara tidak langsung akan mempersempit konflik interpersonal yang dialami, khususnya dalam rumah tangga. Berdasarkan pemaparan tersebut, hipotesis yang diajukan oleh penulis yaitu ada penurunan skor depresi pada korban kekerasan dalam rumah tangga antara sebelum dan sesudah diberikan psikoterapi interpersonal.

\section{Desain Intervensi}

\section{E T ODE}

Intervensi ini dilakukan dengan menggunakan desain kuasi-eksperimen dengan model rancangan intervensi yang digunakan adalah membandingkan rerata skor depresi partisipan antara sebelum dan setelah diberikan intervensi.

\section{Partisipan}

Partisipan dalam intervensi ini ditentukan dengan non-random sampling, di mana partisipan bukan merupakan representasi dari populasi umum karena kategori kasus klinis yang unik, sulit mengambil sampel dalam jumlah besar, dan membutuhkan investigasi mendalam terkait kasus kekerasan dalam rumah tangga yang dialami oleh partisipan. Partisipan dalam intervensi ini berjumlah empat orang dengan kriteria: wanita yang telah menikah lebih dari lima tahun, mengalami kekerasan dalam rumah tangga selama lebih dari setahun (dibuktikan dengan laporan di pusat perlindungan terpadu perempuan dan anak), memiliki gejala depresi, memiliki anak, dan sedang menjalani proses perceraian. Sebelum menjalani proses intervensi, seluruh partisipan telah diberikan informed consent sebagai dokumen kesepakatan intervensi psikologi antara penulis dengan partisipan.

\section{Pengukuran}

Instrumen pengumpulan data utama yang digunakan dalam intervensi ini adalah dengan menggunakan skala depresi. Metode pendukung yang dilakukan adalah observasi dan wawancara. Intervensi ini dilakukan dalam kelompok dengan kategori partisipan yang memiliki permasalahan kekerasan dalam rumah tangga. Skala yang digunakan dalam intervensi ini adalah Beck Depression Inventory (BDI-II) berjumlah 21 item untuk menentukan tingkat depresi yang dialami partisipan (Beck, Brown, \& Steer, 1996). Rentang skor untuk tiap item adalah 0-4, dengan kriteria skor 0-13 termasuk kategori normal, skor 14-19 kategori depresi ringan, skor 20-28 kategori depresi sedang, dan skor 29-63 termasuk dalam 
kategori depresi berat. Koefisien Cronbach's alpha yang menggambarkan reliabilitas BDI-II sebesar 0.902 dengan menggunakan batas kritis sebesar 0.30 .

\section{Analisis Efektivitas Intervensi}

Analisis efektivitas intervensi yang dilakukan penulis adalah menggunakan metode analisis kuantitatif deskriptif dengan menggunakan visual inspection yaitu dengan melihat perubahan sebelum dan setelah diberikannya intervensi. Data akan tersaji dalam bentuk grafik perbandingan dari data deskriptif statistik dengan membandingkan rerata empirik sebelum dan setelah intervensi.

\section{H A S I L I N T E R VE N S I}

Deskripsi data hipotetik diperoleh dari kategorisasi BDI-II di mana skor 0-13 kategori normal, skor 1419 kategori depresi ringan, skor 20-28 kategori depresi sedang, dan skor 29-63 kategori depresi berat. Skor hipotetik yang diperoleh adalah skor minimal $(X m i n)=0$, skor maksimal (Xmax)=63, $M=31.5$ dan $S D=10.5$ pada pre-test dan post-test. Skor empirik yang diperoleh adalah pada pre-test skor minimal $(X \min )=14$, skor maksimal $(X \max )=31$. Pada post -test skor minimal $(X m i n)=5$, skor maksimal $(X m a x)=8$. Perubahan skor depresi tiap partisipan dapat dilihat dalam diagram skor keseluruhan sebelum intervensi dan setelah intervensi dilakukan. Apabila membandingkan hasil pengukuran sebelum $(M=21.5, S D=7)$ dan sesudah intervensi $(M=5.75, S D=61.5)$, rerata tingkat depresi partisipan mengalami penurunan.

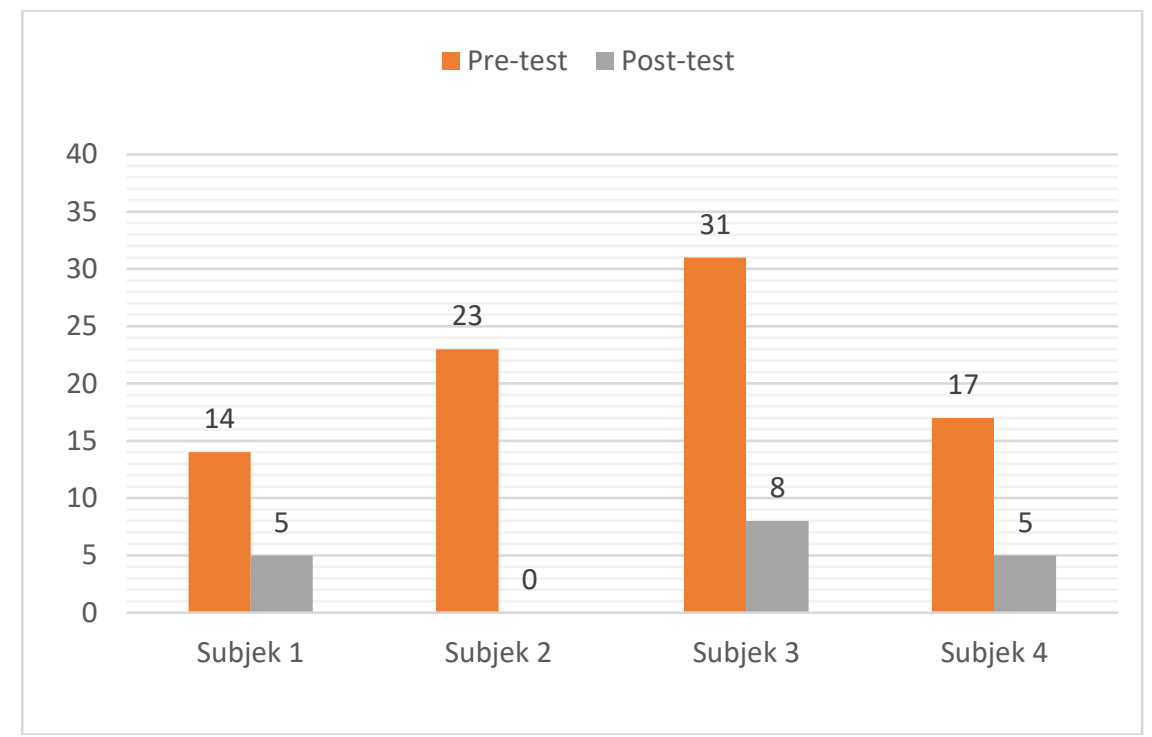

Diagram 1. Skor Keseluruhan Partisipan

Secara kualitatif, perubahan perasaan dan pikiran partisipan dijelaskan dalam Tabel 1. 
Tabel 1. Perubahan Kualitatif Pikiran dan Perasaan Partisipan

\begin{tabular}{cll}
\hline Partisipan & \multicolumn{1}{c}{ Kondisi Sebelum Intervensi } & \multicolumn{2}{c}{ Kondisi Setelah Intervensi } \\
\hline Partisipan 1 & $\begin{array}{l}\text { Perasaan sedih karena merasa sendiri } \\
\text { saat menghadapi masalahnya dan tidak } \\
\text { ada yang memberikan dukungan } \\
\text { psikologis }\end{array}$ & $\begin{array}{l}\text { Merasa bersyukur karena } \\
\text { mendapatkan dukungan dari } \\
\text { perempuan lain yang juga } \\
\text { korban KDRT }\end{array}$ \\
\hline Partisipan 2 & $\begin{array}{l}\text { Mudah marah dan gampang tersulut } \\
\text { emosinya karena hal sepele }\end{array}$ & $\begin{array}{l}\text { Merasa lebih bahagia karena } \\
\text { ada sahabat yang mau } \\
\text { mendengarkan dan berbagi } \\
\text { cerita }\end{array}$ \\
\hline Partisipan 3 & Tidak percaya diri dan merasa tidak \\
& mampu karena ditinggal oleh suami & $\begin{array}{l}\text { Merasa lebih kuat dan lebih } \\
\text { mampu untuk menyelesaikan } \\
\text { masalahnya }\end{array}$ \\
\hline Partisipan 4 & Tidak tenang karena merasa ada emosi \\
& yang tertahan karena marah terhadap \\
mantan suami yang melakukan KDRT & Merasa lebih nyaman, lebih \\
& mudah beristirahat
\end{tabular}

\section{I S K U S I}

Hasil analisis deskriptif menunjukkan adanya penurunan gejala depresi pada perempuan korban kekerasan dalam rumah tangga setelah diberikan psikoterapi interpersonal. Hasil yang diperoleh dari deskripsi data rerata empirik partisipan mengalami penurunan sebelum dan setelah intervensi diberikan. Mean empirik sebelum intervensi 21.5 dan setelah intervensi menurun menjadi 5.75. Hasil analisis deskripsi data kemudian penulis uraikan ke dalam grafik perubahan masing-masing partisipan, di mana hasilnya partisipan mengalami penurunan gejala depresi berdasarkan hasil tes Beck Depression Inventory (BDI-II). Hal tersebut sesuai dengan berbagai penelitian yang menyebutkan bahwa Psikoterapi Interpersonal merupakan terapi yang efektf untuk menangani kasus klinis. Seperti yang dijelaskan oleh Corsini dan Wedding (2011) bahwa psikoterapi interpersonal berfokus untuk mengobati depresi dengan meningkatkan hubungan interpersonal yang bermasalah.

Intervensi ini bertujuan untuk memberikan solusi dengan pendekatan psikoterapi interpersonal dalam menurunkan gejala depresi pada perempuan korban kekerasan dalam rumah tangga. Seperti yang dijelaskan dalam penelitian Sussex dan Corcoran (2005) bahwa perempuan korban kekerasan dalam rumah tangga memiliki peningkatan gejala depresi ketika mengalami konflik dan tidak memiliki teman untuk berbagi. Intervensi ini dilakukan dalam bentuk intervensi kelompok dengan kategori partisipan yang sama-sama memiliki permasalahan kekerasan dalam rumah tangga.

Berdasarkan hasil wawancara yang dilakukan oleh penulis terhadap Pusat Pelayanan Terpadu (PPT) Seruni Semarang, dijelaskan bahwa beberapa alternatif juga sudah diberikan bahkan hingga pendampingan perkara pengaduan hukum, akan tetapi banyak dari korban yang kembali menarik aduan dan belum siap akan perceraian. Wong, dkk. (2009) menyatakan perceraian tidak sepenuhnya membawa dampak negatif. Perceraian juga memberi dampak positif, yaitu terselesaikannya konflik di dalam keluarga, kemandirian, serta kedewasaan. Akan tetapi, dampak negatif yang ditimbulkan dari perceraian orang tua lebih besar dibandingkan dengan dampak positif. Perceraian akan membuat anak tidak mampu melepaskan diri dari konflik orang tua, merasa kehilangan keluarga, kekhawatiran akan dirinya sendiri, rasa khawatir pada orang tua dan saudaranya, sedih, malu, menarik diri dari temantemannya, terganggunya konsep seksualitas ketika dewasa. Hal tersebut yang membuat perempuan

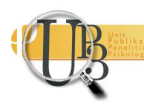


korban kekerasan dalam rumah tangga menjadi sangat sulit dalam menyelesaikan persoalannya dan mempertimbangkan kembali alternatif perceraian dalam rumah tangga.

Auerbach dan Ho (2012) menjelakan bahwa konflik keluarga merupakan pemicu besar penyebab stres interpersonal. Stres tersebut memberikan kontribusi ke tingkat yang lebih tinggi yaitu gejala depresi. Berdasarkan keterangan tersebut dapat disimpulkan bahwa erat kaitannya antara konflik interpersonal dengan gejala depresi. Sehingga dengan memperbaiki konflik interpersonal gejala depresi partisipan akan menurun. Komunikasi yang tidak efektif merupakan alasan utama seseorang mengalami konflik interpersonal (Wurm, Robertson \& Rushton, 2008). Menurutnya dalam penelitian Psikoterapi Interpersonal, terapis harus secara khusus memperbaiki komunikasi yang gagal menjadi lebih efektif.

Psikoterapi interpersonal yang berfokus pada pengobatan depresi tentunya memiliki sasaran untuk pengurangan gejala depresi pada setiap indikatornya, salah satunya perubahan suasana hati. Semula partisipan merasakan sedih, malu, murung, putus asa, merasa tidak dianggap. Seperti yang dijelaskan oleh Auerbach dan Ho (2012), perasaan sedih, marah, putus asa, dan merasa tindak dianggap merupakan bentuk ketidakmampuan dalam berpikir secara rasional. Partisipan yang semula tidak mampu mengidentifikasi dan menganalisa akan permasalahan yang terjadi dan apa dampaknya bagi psikologis setelah mendapatkan intervensi menjadi dapat memahami dan menganalisis gejala depresi yang muncul.

Pada indikator perubahan reaksi fisiologis seperti sakit kepala, sulit tidur, sulit konsentrasi, nafsu makan terganggu, dan mudah lelah. Seperti yang dijelaskan oleh Goldberg (2014) kebanyakan orang hanya mengetahui keterkaitan antara emosi dengan gejala depresi, tetapi pada kenyataannya depresi juga berkaitan erat dengan gejala fisik seperti sakit kepala, sakit punggung, tidur yang bermasalah, perubahan berat badan terkait dengan pola makan yang terganggu, dan gangguan nyeri. Pentingnya seseorang mengetahui keterkaitan antara gejala depresi yang menimbulkan reaksi fisik tersebut, sehingga dapat lebih fokus pada penyembuhan psikologis. Dengan berkurangnya gejala depresi seseorang maka akan berkurang juga gejala fisik yang ditimbukannya. Pada indikator ini partisipan diberikan penjelasan bahwa hal tersebut merupakan dampak dari gejala depresi dan adanya keterkaitan antara psikologis seseorang dan reaksi fisiknya. Oleh sebab dengan emosi yang terkendali dan konflik yang terselesaikan diharapkan reaksi fisik perlahan akan berkurang seiring berjalannya waktu.

Pada akhir sesi psikoterapi interpersonal, ada beberapa manfaat dari terapi yang dirasakan oleh partisipan yaitu; partisipan merasa lebih bersyukur karena ternyata banyak kondiri rumah tangga lainnya yang permasalahannya lebih berat; partisipan merasa lebih bahagia karena memiliki sarana bertukar pikiran dengan yang sama-sama mengalami kekerasan; partisipan merasa lebih mampu menyelesaikan permasalahan dengan baik; dan gejala depresi berkurang dan bahkan ada yang hilang.

\section{S I M P U L A N}

Psikoterapi interpersonal memiliki pengaruh dan terbukti efektif untuk menurunkan gejala depresi pada perempuan korban kekerasan dalam rumah tangga. Hasil diperoleh dengan melihat grafik perubahan masing-masing partisipan, di mana partisipan mengalami penurunan gejala depresi. Grafik tersebut diperoleh dari hasil tes Beck Depression Inventory (BDI-II) yang penulis lakukan sebelum dan setelah memberi perlakuan. Evaluasi tambahan secara kualitatif yang penulis lakukan kepada masingmasing partisipan yang memperoleh hasil positif. Setiap partisipan merasakan perubahan positif setelah mengikuti psikoterapi interpersonal, baik dari segi emosional maupun perilakunya. Partisipan merasa lebih bahagia, lebih bersyukur, dapat berpikir positif, tidak putus asa, dan mampu menyelesaikan permasalahan dengan lebih dewasa. 


\section{P US TAKA ACUAN}

Auerbach, R.P., Ho, M.H.R., \& Kim, J.C. (2014). Identifying cognitive and interpersonal predictors of adolescent depression. Journal of Abnormal Child Psychology, 42(6), 913-924.

Beck, A.T., Brown, G. \& Steer, R.A. (1996). Beck Depression Inventory-II (BDI-II). The Psychological Corporation: San Antonio

Corsini, J. R., \& Wedding, D. (2011). Current Psychotherapies. (Ed. 9). Cengage Learning.

Davey, G. (2008). Psychopathology: Research, Assessment, and Treatment in Clinical Psychology. United Kingdom: Blackwell Publishing.

Goldberg, D.P. (2014). Anxious forms of depression. Depression and Anxiety, 31(4), 344-351.

Gumilang, A. (2017). Ratusan Kasus Kekerasan terhadap Perempuan terjadi di Jateng tahun 2017. Diakses dari http://jateng.tribunnews.com/2017/12/07/ratusan-kasus-kekerasan-terhadapperempuan-terjadi-di-jateng-tahun-2017 pada tanggal 3 Januari 2018.

Haqqi, S., \& Faizi, A. (2010). Prevalence of Domestic Violence and associated Depression in married women at a Tertiary care hospital in Karachi. Procedia-Social and Behavioral Sciences, 5, 10901097.

Brunstein-Klomek, A., Zalsman, G., \& Mufson, L. (2007). Interpersonal psychotherapy for depressed adolescents (IPT-A). Israel Journal of Psychiatry and Related Sciences, 44(1), 40-46.

Niaz, U. (2003). Violence against women in South Asian countries. Archives of Women's Mental Health, 6(3), 173-184.

Neuman, W. L. (2006). Social Research Methods: Qualitative and Quantitative Approach. (Ed. 6). Boston: Pearson Education.

Sussex, B., \& Corcoran, K. (2005). The Impact of Domestic Violence on Depression in Teen Mothers: Is the Fear or Threat of Violence Sufficient? Brief Treatment and Crisis Intervention, 5(1), 109-120.

Wong, D. L. (2009). Buku Ajar Keperawatan Pediatrik Volume 1. (Ed. 6). Jakarta: Buku Kedokteran EGC.

Wurm, C., Robertson, M., \& Rushton, P. (2008). Interpersonal psychotherapy: an overview. Psychotherapy in Australia, 14(3), 46. 